Discourse and Communication for Sustainable Education, vol. 8, no. 1, pp. 32-52, 2017

\title{
Exploring the Role of Future Perspective in Predicting Turkish University Students' Beliefs About Global Climate Change
}

\author{
Deniz Ateş and Gaye Teksöz \\ Middle East Technical University, Turkey \\ Hamide Ertepınar \\ Istanbul Aydın University, Turkey
}

\begin{abstract}
Recent studies indicate that limited understanding about causes and its potential impacts of climate change and fault beliefs by people across different countries of the world including Turkey is a real challenge. Acceptance of climate change as a real threat, believing its existence, and knowing causes and consequences are very significant for climate change adaptation and mitigation. Therefore, exploring underlying factors shaping or affecting beliefs of people is needed for designing educational interventions for a change in individuals' attitudes and behaviours. The main purpose of the present study was to explore how and to what extent future time perspective, perceived knowledge about global climate change, and environmental attitudes explain the university students' beliefs about occurrence, causes and consequences of GCC. A quantitative research was conducted with the participation of one thousand, five hundred and eighty undergraduate students $(\mathrm{n}=1580)$ of METU and the data was gathered through Future Perspective Related Beliefs about Global Climate Change Scale. The study findings suggested that ecocentric attitude and perceived knowledge are mainly two influential factors for the undergraduate students' beliefs about global climate change. Future time perspective's contribution although low, was found to be significant in beliefs about GCC. The results of this study would shed light to evaluate and improve educational programs and curriculum in higher education, and can be a guide because Turkish literature does not serve any research that seek students' future time perspective related to global climate change.
\end{abstract}

Keywords: future perspective, higher education, climate change education, climate change beliefs, sustainable development. 


\section{Introducation}

\section{The Problem}

Climate change is a global threat of the twenty-first century with long-term impacts for the sustainable development of countries in the world. In the presence of global climate change, international and national institutions, policy makers, higher education researchers and academics have increasingly redirected their attention to social and economic sustainability in the world (Gray, 2010). Since the sustainable development provides a future sighted and long term perspective on development concerning the issues like energy resources, disaster management, population growth and consumption, global climate change threats brought the issue back to the sustainable development instead of the short term development efforts (IPCC, 2001).

For adaptation and mitigation efforts to be effective, establishment of national and international policies, development and transfer green technologies and financial incentives are needed, but they are not sufficient for responding the challenges of sustainable development and global climate change (Nolet, 2009; Buckler, \& Creech, 2014; Besong, \& Holland, 2015; Salite, 2015). Since human actions are linked to causes of greenhouse gas emissions, deep and lasting behavioral changes are also necessary for adaptation to and mitigation of global climate change (Nolet, 2009). Education is considered as a key instrument for bringing about this behavioral change (Buckler, \& Creech, 2014); and also found its place in climate change adaptation and mitigation agenda as an effective strategy (Makrakis, Gkotzos, \& Larios, 2013; Chew-Hung, 2014).

For last four decades, increasing environmental concern around the world has raised the importance of education. Education has been seen as the primary agent in transformation towards sustainable development (Pipere, Veisson, \& Salite, 2015). The main idea behind this thought is that education enables individuals to gain awareness and take informed decisions in the face of global climate change. Therefore, education plays an important part in achieving sustainable development (Nolet, 2009) and the term Education for Sustainable Development (ESD) is referred to an overarching framework for various aspects of education related to environmental, economic and social aspects of sustainable development (Sterling, 2004). Environmental protection implies future concern, in which natural resources are preserved and secured for future generations. Even the most cited definition of sustainable development takes account of future concern, stating that "sustainable development should meet the needs of the present without compromising the needs of future generations." In this respect, sustainability concept is about both short term and long term time perspective; and requires individuals to pay attention to the short term and the long-term gains and effects of their choices, and to take responsibility for the effects of their decisions and actions on future generations (Gibson, 2006). Therefore, future perspective is also considered as an important element in ESD (Frisk, \& Larson 2011; Wiek, Withycombe, \& Redman, 2011; Pipere, Veisson, \& Salìte, 2015; Bakutytè, Ušeckienè, \& Iliško, 2016).

The Climate Change Education for Sustainable Development (CCESD), on the other hand, emerged as an integral part of ESD. During the UNESCO World Conference on ESD held in Bonn in 2009, climate change was accepted as a key action theme of the UNDESD with an emphasis on education as an essential element of the global response to climate change (UNESCO, 2014). CCESD is considered as an important tool for enabling students to be aware of global climate change threat, know about root causes, 
negative consequences, and gain relevant skills and dispositions to act for mitigation and adaptation of global climate change (Kagawa, \& Selby, 2010; Makrakis, Gkotzos, \& Larios, 2013). Future time perspective is particularly of importance for global climate change. As its consequences will be felt at least next thousands years (IPCC, 2007), for mitigation and adaptation of negative consequences of climate change, individuals should take into account long-term consequences of their behaviors (Milfont, \& Demarque, 2015).

Recent studies indicate that limited understanding about causes and its potential impacts of climate change and fault beliefs by people across different countries of the world including Turkey is a real challenge. Acceptance of climate change as a real threat, believing its existence, and knowing causes and consequences are very significant for climate change adaptation and mitigation. In addition, the past few years have seen an increase in studies examining the extent to which future concerns are associated with environmental engagement. These studies have suggested some evidence that future time perspective influences proenvironmental attitudes and behaviors of individuals (Corral-Verdugo, Fraijo-Sing, \& Pinheiro, 2006; Milfont, \& Gouveia, 2006; Strathman, Gleicher, Boninger, \& Edwards, 1994). Therefore, exploring underlying factors shaping or affecting beliefs of people is needed for designing educational interventions for a change in individuals' attitudes and behaviours (Gifford et al., 2011; van der Linden, 2014; Keinonen et al., 2016).

Findings of the studies conducted during the last decade in Turkey indicated that although students are aware of global climate change and concerned about consequences, they hold some misconceptions related to global climate change; they do not have adequate knowledge about causes and consequences, and more importantly, they are not aware of the link between individual behaviours and the causes of climate change (Senel, \& Gungor, 2008; Kahraman et al., 2008; Bozdogan, 2009; Kilinc, Boyes \& Stanisstreet, 2011; Sever, 2013; Sahin, 2013; Ozdem et al., 2014).

There is still an important minority in the world who believe that global climate change is caused by natural processes, or it is not occurring at all (Leiserowitz, Maibach, Roser-Renouf, Smith, \& Hmielowski, 2012; Shao, 2012). According to a survey of $2010,19 \%$ of Americans think that climate change is not happening, and another $19 \%$ does not know if it is happening (Leiserowitz et al., 2012). Likewise, $18 \%$ of Australians and $15 \%$ of British people do not believe that climate change is happening (Reser, Bradley, Glendon, Ellul, \& Callaghan, 2012). In addition to these two faulty beliefs about occurrence and causes of global climate change, there is another belief about global climate change: belief that global climate change will bring about negative consequences. This belief has been generally defined as risk perception (Bord et al., 2000; Leiserowitz, $2005)$. The findings of the most current public opinion poll indicated that $64 \%$ of the Americans do not see global warming as a threat; $69 \%$ of them believe that there is a solid evidence for existence of climate change (Gallup Poll, 2013). 50\% of all Europeans does not think that climate change is one of the world's most serious problems (Eurobarometer, 2014). 


\section{Insights from the Literature Review}

The findings of previous studies have suggested mainly two types of factors related individuals' beliefs about climate change, or barriers causing limited understanding of climate change: nature of the climate change phenomenon and psychological factors related to time perspective of individuals.

Climate change is in many respects different from other environmental problems and often described as a complex problem (Dietz \& Stern, 1998). The impact of climate change varies, while some regions suffer more severe effects of climate change, in the other parts of world its impacts are modest. Besides, some negative effects are projected to occur in the future. The impacts of global climate change are much more gradual than other environmental problems, so this makes it more difficult to realize. Thus, most people consider climate change impacts as both uncertain and as being mostly in the future and geographically distant, all factors that lead people to ignore them (Zimmerman, 2011).

Misperceptions about causes and consequences of climate change are explained within two contexts in the literature, namely social dilemma and construal level theory. Social dilemma is defined generally as the situations in which short-term individual and long-term collective interests conflict (Komorita \& Parks, 1994; Messick \& McClelland, 1983). Considering pro-environmental behaviour as a social dilemma suggests that when individuals are offered a choice between more and less environmental friendly behaviours, in order to make a decision, they are faced with at least two basic underlying conflicts of interest: a social conflict (between individual and collective interests) and a temporal conflict (between immediate and future consequences of their actions).

In fact, almost any pro-environmental behaviour causes a temporal conflict, as in most cases, long-term interests require the sacrificing of short-term interests (Balliet, \& Ferris, 2013). For example, a conflict emerges when a person decides whether to turn on a heater or put on another piece of clothing. Turning on the heater will provide immediate benefit an individual in the short run, but it may cause more energy consumption and major damage in the future and be detrimental to long-term interests (Carmi, 2013). Therefore, considering future consequences of behaviours is important for individuals' willingness to act cooperatively for mitigating harmful effects of global climate change (Beckenkamp, 2011).

Construal Level Theory (CLT) is a socio-psychological theory that describes how psychological distance influences individuals' thoughts and behaviour (Liberman \& Trope, 2008). According to CLT, individuals perceive an event away from direct experience on four psychological distances: temporal distance (time, i.e., it takes place far into the future); spatial distance (physical space, i.e., it occurs in more remote locations); social distance (interpersonal distances, i.e., it happens to people less like oneself); and bypothetical distance (predicting that an event is less likely or unlikely to occur) (Trope, \& Liberman, 2010; Trope, Liberman \& Wakslak, 2007).

When individuals' beliefs about occurrence, causes and consequences of global climate change are considered within CLT framework, due to the nature or characteristics identified above, people construe global climate change as an abstract and psychologically distant phenomenon on all four psychological distances. Basically, as effects of climate change are not felt seriously at the same degree in all countries, climate change becomes removed from individuals' direct experience, they believe that it has not being actually 
happened. As Milfont (2010) stated, as a general, people typically perceive climate change as a distant threat, one that is not relevant to them personally, where they live, and not in the present time but some time in future.

Several studies explored the different aspects of psychological distance and its influence on environmental engagement and environmental risk perception (WadeBenzoni, 2008; Gifford et al., 2011; Milfont, Abrahamse, \& McCarthy, 2011; Spence, Poortinga, \& Pidgeon, 2012). These studies found that lower psychological distances was associated with higher levels of concern, and significantly related to behavioural intention (i.e., preparedness to act on climate change).

Since the temporal conflicts are related to the consideration of long-term outcomes of behaviours; and temporal psychological distance plays a central role in exploring time perspective phenomena, an individual's future time perspective is particularly relevant to an individual's beliefs and decision to engage in behaviour for mitigation and adaptation of global climate change.

Future Time Perspective (FTP) is individuals' ability to foresee and anticipate the future, and reflects people's capacity to plan for and achieve future goals (Zimbardo, \& Boyd, 1999; Bakutyte, Ušeckienè, \& Iliško, 2016) and to consider the future implications of their actions (Strathman et al., 1994). It is a motivational and an individual-differences construct (Carmi, 2013). Some people can foresee the future implications of their present behaviour, understand how their present behaviour is meaningfully related to desired future goals, and how their present behaviour serves the attainment of those future goals. Other people live in the present and do not anticipate the future consequences of their present behaviours (Milfont, \& Demarque, 2015).

The Consideration of Future Consequences (CFC) is (Strathman, Gleicher, Boninger, \& Edwards, 1994) is one of the FTP measures for assessing individual differences in construct of future perspective. The CFC is a motivational construct, it enables an individual to perceive what is his or her future might require or demand behaviorally, in order to attain desired outcomes (Pertrocelli, 2003). The CFC hypothesizes that particular individuals resolve the dilemma between present and future in favor of one or the other is a relatively stable characteristic. Moreover, individuals low in CFC are expected to focus more on their immediate, versus distant, needs and concerns, and are thus expected to act to satisfy these immediate needs. At the extreme end, individuals may not even consider future consequences of their behavior. People who are high in CFC are expected to consider the future implications of their behavior and to use their distant goals as guides for their current actions. At the extreme end, they may not consider immediate implications at all (Strathman et al., 1994).

Strathman and colleagues (1994) found that college students who scored higher in CFC also expressed more pro-environmental attitudes toward offshore drilling. Lindsay and Strathman (1997) studied a sample of Missouri residents by means of a telephone survey and found that higher CFC significantly predicted recycling behavior. Joireman, Lasane, Bennett, Richards, and Solaimani (2001) also used CFC in a sample of college students and reported that higher CFC was positively related to stronger intentions to engage and to more frequent actual engagement in pro-environmental activism. In a study of citizens in a Mexican city, stronger CFC was positively related to water conservation (Corral Verdugo, Fraijo-Sing, \& Pinheiro 2006), affinity toward diversity, and general ecological behavior (Corral-Verdugo, Bonnes, Tapia-Fonllem, Fraijo-Sing, Frias-Armenta, \& Carrus 2009). 
A significant amount of studies has indicated that knowledge about the causes of climate change is an important predictor of climate change mitigation intentions (Bord, O'Connor, \& Fisher, 2000; Hidalgo, \& Pisano, 2010; O’Connor et al., 1999; Whitmarsh, 2009a). Lazo and colleagues (2000) reported that more knowledgeable persons perceive higher risk than do less knowledgeable persons. Regarding to global climate change, lack of basic knowledge about climate change has been noted as an important hindrance for mitigation and adaptation of climate change (Lorenzoni, Nicholson-Cole, \& Whitmarsh, 2007; Semenza et al., 2008).

Environmental Attitudes are "the collection of beliefs, affect, and behavioural intentions a person holds regarding environmentally related activities or issues" (Schultz, Shriver, Tabanico, \& Khazian, 2004, p. 31). Ecocentrism and anthropocentrism are the two distinct value orientations shaping individuals' concern for the environment (Thompson \& Barton, 1994). Both ecocentric and anthropocentric individuals are concerned for the environment, but their motivation and values underlying their concern are different. Anthropocentric individuals' concern is to protect environment for maintaining and enhancing quality of life for humans. Ecocentric individuals attach importance to the environment or the nature for its intrinsic value and would engage in climate change mitigation behaviour, even if it involves some sort of sacrifice on their part.

Environmental attitudes are strongly associated with concern for, awareness of risks, and supportive action for risk prevention. For example, Nilsson, von Borgstede, and Biel (2004) found that willingness to support climate change mitigation policy was positively related to ecocentric values. Some studies have confirmed that people who ecocentric values are more likely to report concern about the risks and consequences of climate change (Brody, Zahran, Vedlitz, \& Grover, 2008; Corner et al., 2011; Poortinga et al., 2011) and are less likely to be sceptical about the reality or seriousness of the problem (Whitmarsh, 2011).

Gender has been reported in the majority of the recent studies pertaining to beliefs about global climate change as having an influential effect. Research consistently indicates that women are more likely to believe in global warming (Bord \& O'Connor, 1997; Malka, Krosnick, \& Langer, 2009; McCright, 2010; Park, \& Vedlitz, 2013; Semenza et al., 2008; Sunblad, Biel, \& Garling, 2007), gather information on global warming (Scannell, \& Gifford, 2013), engage in consumer behaviours to mitigate global warming (Bord, \& O’Connor,1997; Meier, \& Christen, 2012; O’Connor, Bord, \& Fisher, 1999; Park \& Vedlitz, 2013), and support climate change mitigation policies (Maibach, Leiserowitz et al., 2012; McCright, Dunlap, \& Xiao, 2013). Future time perspective studies indicate the gender effect, for example, Zimbardo, Keough, and Boyd (1997) found that in general college-aged men are more present-oriented than their female counterparts, and females are more future-oriented.

\section{The Aim of the Study}

Considering the importance of future time perspective in climate change education and the research gap in the literature, this research was intended to shed light on how and to what extent future time perspective along with perceived knowledge and environmental attitudes might be useful in explaining the undergraduate students' beliefs about occurrence, causes and consequences of global climate change. This study attempted to shed light into following research questions: 
1. How well do perceived knowledge and environmental attitudes predict the belief about occurrence, causes and consequences of global climate change, controlling for gender?

2. To what extent does the future time perspective predict three beliefs about global climate change (i.e., belief about occurrence, causes and effects about global climate change) over and above the other variables, controlling for gender?

\section{Method}

\section{Research Participants}

One thousand five hundred and eighty undergraduate students $(n=1580)$ from one of the largest state universities in Turkey (METU) participated in the study during the fall semester of 2014. 55.8\% (N=881) of the participants were female and $44.2 \%$ $(\mathrm{N}=699)$ of them were male. Mean age of the undergraduates was $20.81(\mathrm{SD}=1.52)$. $44.9 \%(\mathrm{~N}=709)$ were from Faculty of Engineering; $18.2 \%(\mathrm{~N}=288)$ were from Faculty of Arts and Science; $14.8 \%(\mathrm{~N}=234)$ were from Faculty of Economics and Administrative Sciences; $14.8 \%(\mathrm{~N}=234)$ were from Faculty of Education; and finally $7.3 \%(\mathrm{~N}=115)$ were from the Faculty of Architecture. In terms of the grade level, 42.4\% ( N=670) of the undergraduate students were sophomore; $23 \%(\mathrm{~N}=364)$ of them were junior, $20.1 \%$ $(\mathrm{N}=318)$ of them were freshman; and $14.4 \%(\mathrm{~N}=228)$ of them senior students.

\section{Sampling Procedures}

Volunteer undergraduate students were selected through convenient sampling method. In order to reflect the departmental and grade level diversity in the sample of the study, the students taking elective courses were chosen intentionally, as these courses are open for all students from different departments at different grade levels. The permission University Human Subjects Ethics Committee was obtained in order to collect the data. The pilot study was carried out with the participation of 197 volunteer undergraduate students in order to test the validity and reliability of the instruments during the summer school held in July of 2014. In the light of the results proposed in validity and reliability analyses, the main study was conducted. Both pilot and main study were conducted in classroom environment under standard conditions. All undergraduate students filled out the questionnaire on voluntary basis, and all the data were collected by the researcher. It took students approximately 10 minutes to complete the entire questionnaire.

\section{Instruments / Scales}

Future Perspective Related Beliefs about Global Climate Change Scale was used as data collection instrument. It is a paper and pencil measure containing 55 closed-ended questions under five distinct dimensions. Each dimension, however, consists of a scale. Demographic Form consists of four questions to provide information about students' gender, age, department and grade level. Beliefs about Global Climate Change Measure 
(BGCCM) originally developed by Heath and Gifford (2006) adapted into Turkish by the author. It contains a total of 14 questions. The responses for all questions are given in five-point Likert format ranged from 1 (strongly disagree or very unlikely, depended on the wording of the question) to 5 (strongly agree or very likely). Perceived knowledge about climate change was measured by asking the following question: "I would say my technical knowledge about global climate change is minimal, limited, moderate, extensive, and professional." It was coded from 1 to 5. Environmental Attitude Scale (EAS) originally developed by Thompson and Barton (1994) to assess eco-centric, anthropocentric attitudes and apathy for environment. The scale was adapted into Turkish by Eryigit (2010). For this study only ecocentric and anthropocentric items were utilized. Ecocentric attitudes are measured with 12 items and anthropocentric attitudes are measured with 10 items. The scale items are rated on a 5 -point Likert scale $(1=$ strongly disagree to $5=$ strongly agree). Consideration of Future Consequences Scale (CFCS) originally developed by Strathman and his colleagues (Strathman et al., 1994) was adapted into Turkish by Cinan and Dogan (2013). It consists of two dimensions as one assessing the concern with future consequences (CFC-Future) and another one assessing the concern with immediate consequences (CFC-Immediate). CFCS comprises 14 items related to future ( 7 items) and immediate ( 7 items) consequences of present actions. Responses are on a 7 -point scale ( 1 = very uncharacteristic of me; 7 = very characteristic of me) with reverse scoring of 7 immediate-focused items. The high score indicated future time perspective and low score indicated present time perspective

\section{Research Design}

In order to explore the research questions of this study i.e., whether the future time perspective would have unique role over and above the other variables in predicting the three beliefs about global climate change (i.e., belief about occurrence, causes and effects of global climate change), three separate hierarchical multiple regression analyses were conducted with three outcome and four predictor variables. The outcome (dependent) variable in this study was beliefs about global climate change and composed of three conceptually different beliefs: (a) the belief that global climate change is occurring, (b) the belief about possible causes of global climate change, and (c) the belief of possible consequences of global climate change. The predictor variables are perceived knowledge about global climate change, environmental attitudes with two distinct variables as ecocentrism and anthropocentrism, and future time perspective. Gender was the control variable. In each of three hieararchical regression analyses, gender was entered at the first stage of the regression as the control variable; perceived knowledge about global climate change, ecocentric and anthropocentric attitude were added at the second stage; and finally, future time perspective was entered at the third stage. Before conducting regression analyses, in order to understand the participants' positions and characteristics concerning the variables of the study, descriptive analyses of the undergraduate students' responses to the items of scales were carried out by means of calculating the frequencies in percentage. Furthermore, prior to regression analyses, in order to determine whether linear relationships exist among the variables of this study correlation analysis was conducted. 


\section{Research Findings}

Undergraduate Students' Beliefs about Global Climate Change: Undergraduate students were asked to indicate their beliefs about global climate change on three dimensions: that global climate change is occurring, is caused mainly by humans, and will have negative consequences. Majority of the undergraduate students believed that global warming was occurring $(87.7 \%)$; caused mainly by human activities $(78.1 \%)$; and would bring about negative consequences (93\%). On the other hand, $16.3 \%$ of them were not sure or $5.9 \%$ did not believe the occurrence of climate change; $15.4 \%$ were unsure about or $6.5 \%$ did not believe that human activities caused global climate change and $9.6 \%$ believed that global warming was due to natural causes; and $25 \%$ was not sure about or $10 \%$ did not believe that consequences of global warming would be harmful for the environment.

Undergraduate Students' Future Perspective: Almost all of undergraduate students $(92.6 \%)$ declared that their behavior was generally influenced by future consequences; and when making a decision they thought of how it might have affected them in the future $(95.5 \%)$.

According to the results of the bivariate correlations among the variables of the study presented in Table 1, among 64 correlations, 62 of them were significant. To be more precise, the correlation coefficients among all variables of the study were statistically significant, except for gender which was not significantly correlated with perceived knowledge $(r=-.02, p>.01)$, and belief about causes $(r=-.02, p>.01)$. However, gender was significantly correlated with all other variables. The highest positive correlation coefficient is between belief about causes of GCC and belief about consequences of GCC $(r=.57, p<.01)$. There are strong correlations between the belief about consequences of global climate change and belief about causes $(r=.57, p<.01)$; between belief about consequences and belief about occurrence $(r=.51, p<.01)$; and between belief about occurrence and belief about causes $(r=.44, p<.01)$, respectively. This means that, however, believing that climate change is a human induced phenomenon and that it brings about harmful effects for human and natural environment depend on and/or relate with the belief that it really occurs. As expected ecocentric attitude negatively correlated with anthropocentric attitude $(r=-.25, p<.01)$, and positively correlates with gender $(r=.20$, $p<.01)$; perceived knowledge $(r=.17, p<.01)$; belief about occurrence $(r=.33, p<.01)$, causes $(r=.31, p<.01)$, and consequences of global climate change $(r=.39, p<.01)$; anthropocentric attitude is negatively associated with all variables. Finally, future time perspective has moderate negative correlation with anthropocentric attitude $(r=-.21, p<.01)$; low positive correlations with belief about consequences $(r=.18, p<.01)$, belief about causes $(r=.15, p<.01)$, and belief about occurrence $(r=.14, p<.01)$ of global climate change. This means that consideration of future consequences of current behaviors relates with three beliefs about global climate change and environmental attitudes (Table 1). 
Table 1

Pearson Correlation Coefficients of the Study Variables

\begin{tabular}{|c|c|c|c|c|c|c|c|c|}
\hline Variables & 1 & 2 & 3 & 4 & 5 & 6 & 7 & 8 \\
\hline \multicolumn{9}{|l|}{ Gender } \\
\hline Perceived knowledge about GCC & -.02 & & & & & & & \\
\hline Belief about occurrence of GCC & $.18^{* * *}$ & $.29^{* *}$ & & & & & & \\
\hline Belief about causes of GCC & -.02 & $.21^{* *}$ & $.44^{* *}$ & & & & & \\
\hline Belief about consequences of GCC & $.11^{* *}$ & $.23^{* *}$ & $.51^{* *}$ & $.57^{* *}$ & & & & \\
\hline Ecocentric attitude & $.20^{* * *}$ & $.17^{* * *}$ & $.33^{* * *}$ & $.31^{* *}$ & $.39^{* * *}$ & & & \\
\hline Anthropocentric attitude & $-.12^{* *}$ & $-.10^{* * *}$ & $-.17^{* * *}$ & $-.22^{* *}$ & $-.21^{* * *}$ & $-.25^{* *}$ & & \\
\hline Future time perspective & $.09^{* *}$ & $.14^{* * *}$ & $.19^{* *}$ & $.15^{* *}$ & $.18^{* * *}$ & $.26^{* *}$ & $-.21^{* *}$ & \\
\hline
\end{tabular}

According to the results of hierarchical regression analysis presented in Table 2, the results of standardized coefficients indicated that ecocentric attitude positively predicted the undergraduate students' belief about occurrence of global climate change with a highest beta value $(\beta=.24, p<.05)$, followed by perceived knowledge about global climate change $(\beta=.23, p<.05)$, gender $(\beta=.12, p<.05)$, and future time perspective $(\beta=.08, p<.05)$. Moreover, it was found that anthropocentric attitude $(\beta=-.06, p<.05)$ negatively predicted the undergraduate students' belief about occurrence of global climate change. To be more precise, having more ecocentric attitude and perception of being more knowledgeable about global climate change, with less anthropocentric attitude contributed to the undergraduate students' belief that global climate change is a real phenomenon and occurring.

Table 2

Summary of $R^{2}, \Delta R^{2}$ and Beta Values in Hierarchical Regression Analysis for Variables Predicting Three Beliefs about GCC

\begin{tabular}{lccccccccc}
\hline \multirow{2}{*}{ Variable } & \multicolumn{2}{c}{$\begin{array}{c}\text { Belief about } \\
\text { occurrence of GCC }\end{array}$} & \multicolumn{2}{c}{$\begin{array}{c}\text { Belief about causes } \\
\text { of GCC }\end{array}$} & \multicolumn{4}{c}{$\begin{array}{c}\text { Belief about } \\
\text { consequences of GCC }\end{array}$} \\
\hline & $\mathrm{R}^{2}$ & $\Delta \mathrm{R}^{2}$ & $\mathrm{~B}$ & $\mathrm{R}^{2}$ & $\Delta \mathrm{R}^{2}$ & $\beta$ & $\mathrm{R}^{2}$ & $\Delta \mathrm{R}^{2}$ & $\beta$ \\
\hline Model 1 & .031 & .031 & & .000 & .000 & -.088 & .012 & .012 & \\
\hline Gender & & & .120 & & & & & & .031 \\
\hline Model 2 & .184 & .154 & & .147 & .146 & .143 & .194 & .183 & \\
\hline Perceived knowledge & & & .231 & & & .253 & & .159 \\
\hline Ecocentric attitude & & & .240 & & & -.149 & & & .321 \\
\hline Anthropocentric attitude & & -.060 & & & & & & -.104 \\
\hline Model 3 & .190 & .006 & & .148 & .001 & .039 & .197 & .002 & \\
\hline Future time perspective & & .075 & & & -.088 & .012 & & .049 \\
\hline
\end{tabular}
$p<.05$.

In addition, the results of standardized coefficients indicated that ecocentric attitude made the strongest unique contribution to explaining the undergraduate students' belief about causes of global climate change $(\beta=.253, p<.05)$, followed by anthropocentric attitude $(\beta=-.149, p<.05)$ and perceived knowledge about global climate change $(\beta=.143$, $p<.05)$. To be more precise, having ecocentric attitude and perception of being more 
knowledgeable about global climate change, with less anthropocentric attitude contributed to the undergraduate students' belief that global climate change has been caused mostly by human activities.

Finally, ecocentric attitude made the strongest unique contribution to explaining the undergraduate students' belief about consequences of global climate change $(\beta=.321$, $p<.05)$, followed by perceived knowledge about global climate change $(\beta=.159, p<.05)$, and anthropocentric attitude $(\beta=-.104, p<.05)$. However, future time perspective $(\beta=.049, p<.05)$ made the weakest contribution to explaining belief about consequences of global climate change; and the contribution of gender was found not to be significant $(\beta=.031, p>.05)$. To be more precise, having ecocentric attitude and perception of being more knowledgeable about global climate change, with less anthropocentric attitude contributed to the undergraduate students' belief that global climate change brings about harmful consequences.

\section{Discussion}

The results of hierarchical regression analysis revealed that perceived knowledge about global climate change, anthropocentric attitudes, ecocentric attitudes, gender and future time perspective made significant contribution to prediction of undergraduate students' beliefs that global climate change is occurring, caused by human activities and will bring about harmful consequences. Collectively, the predictor variables explained $19 \%$ of the variance in the undergraduate students' belief about occurrence of global climate change; $14.8 \%$ of the variance in the undergraduate students' belief about causes of global climate change; and $19.7 \%$ of the variance in the undergraduate students' belief about consequences of global climate change. In explaining of all three beliefs, ecocentric attitude and perceived knowledge about global climate change were found to be made the highest contribution. Future time perspective's contribution although low, was found to be significant in all three beliefs about global climate change. However, gender made no contribution to the undergraduate students' belief that global climate change is caused by human activities. The present study findings suggested that ecocentric attitude and perceived knowledge are mainly two influential factors for the undergraduate students' beliefs about global climate change.

As the findings indicated, despite beliefs of the majority, there is still an important minority who believe that global climate change is caused by natural processes, or its consequences would be harmful, or it is not occurring at all. These findings are consisted with the results of other national and international surveys about the Turkish public perceptions about global climate change (Ministry of Environment and Urbanization, 2012; Ipsos MORI, 2014). Moreover, most of the researchers reported the same trend in public beliefs elsewhere in the world (Gallup Poll, 2013; Eurobarometer, 2014; Leiserowitz, Maibach, Roser-Renouf, Smith, \& Hmielowski, 2012; Shao, 2012; Reser, Bradley, Glendon, Ellul, \& Callaghan, 2012).

Majority of the undergraduate students perceived that they had moderate (49\%) or limited $(25 \%)$ knowledge about causes and consequences of global climate change. These findings confirmed the results of previous studies suggested that the Turkish students did not have adequate knowledge about causes and consequences, and more importantly, they were not aware of the link between individual behaviors and the causes of climate change (Senel, \& Gungor, 2008; Kahraman et al., 2008; Bozdogan, 2009; 
Sever, 2013; Ozdem et al., 2014); and of a national survey stated that people in Turkey have a concern and interest but no adequate knowledge about a climate change (Ministry of Environment and Urbanization, 2012).

Likewise, international research on individuals' knowledge of climate change often revealed that most people, even those considered well-educated, have a minimum understanding of the causes of climate change (Bord, O'Connor, \& Fisher, 2000; Hidalgo \& Pisano, 2010; O'Connor et al., 1999; Whitmarsh, 2009b). As Grotzer and Lincoln (2007) pointed out, the lack of knowledge about climate change may not be surprising given the complexity of the issue and lack of opportunity to learn about it for, "the current adult population grew up at a time when the curriculum did not offer the understandings necessary to enable people to understand the language or pattern of nature in general or climate change in particular" (p. 267).

The findings revealed that the undergraduate students had ecocentric attitude, rather than anthropocentric attitude towards environment. They believed conserving nature and respecting environment for the sake of nature, and not because of its perceived importance to human beings. This finding was confirmed by many studies in Turkey which consistently showed that youth in Turkey often had an ecocentric attitudes (e.g., Tuncer, 2008; Tuncer, Ertepinar, Tekkaya, \& Sungur, 2005).

As the results indicated, the undergraduate students consider the future outcomes of their present behaviors, think of and care about their future. These findings have been confirmed by some other studies emphasizing influence of cultural differences in socialization on future time perspective. For example, Gailly (1982) argued that social and cultural differences determined in motivation and future time perspective. Gailly found out that the Belgian and Turkish youth differed in future time perspective and motivational contents since their parents differed in degree of modernism and in value orientations. On the other hand, Kabasakal and Dastmalchian (2001) proposed that like in other Middle East countries, in the Turkish culture believing fate and destiny was a strongly rooted cultural aspect, and the concept of destiny in Islam was a factor negatively influencing future orientation of societies.

However, despite the concept of destiny observed at the societal level, the young generation in Turkey tended to be more future oriented, as globalization and modernization changed the traditional Turkish society. Likewise, the most recent study conducted to explore the cultural differences in terms of time perspective with a sample $(\mathrm{N}=7942)$ from 23 countries, including Turkey also confirmed this finding. The study found that the Turkish participants were rather future oriented than present. In that study, the mean scores of the Turkish sample $(\mathrm{N}=432)$ were reported that future perspective as 3.89 out of $5(\mathrm{SD}=.50)$ (Sircova et al., 2015).

According to the results of the study female students had stronger beliefs that global climate change is occurring; a human induced problem; and will have negative consequences; had more ecocentric attitudinal motivation, and future time perspective than did male students. The findings of this study confirmed the gender-effect which has been referred extensively by most of environmental or sustainability studies both in Turkey (e.g., Tuncer, Ertepinar, Tekkaya, \& Sungur, 2005; Sahin, Ertepinar, \& Teksoz, 2012; Yżlmaz, Boone, \& Anderson, 2004) and in other countries (e.g., Milfont \& Duckitt, 2010; Zelezny, Chua, \& Aldrich, 2000; Milfont, 2012).

Long-term and a deep-rooted social change for sustainability can be enhanced progressively through education (Dobson, 2003). In the face of global climate change, 
higher education institutions should take the responsibility to educate young generation in a way to equip them with necessary knowledge, skills and competences that enable them to encounter the future challenges and unforeseeable harmful effects of global climate change. Mitigation and adaptation related to negative effects of global climate change require an informed and engaged public and an education system that provides students with the knowledge they need to make informed choices about responses to climate change.

Climate change will impact significantly on the wellbeing of future generations. Therefore, it is important to enhance future thinking skills of university students. Students should be aware that their current actions and decisions will effect on future environmental problems. Thus, education and training should be relevant for this purpose. Through certain appropriate instruction methods such as scenario construction, role playing and simulations, case studies, and by making use of information technologies, educational programs and university courses should be designed to enable students to imagine how the future could be and how their present actions and decisions will impact the life of their own and the other people living in their country or in other parts of world (Pruneau et al., 2016).

Education is a personal endeavour to encounter the future and education plays important role in defining future orientations of students. Therefore, higher education institutions should enable students to involve in constructing alternative and desirable future scenarios; make students see undesirable future effects of unsustainability, and create favorable, open-minded and reflective learning environments where students can find out their potential for a sustainable future and freely discuss and negogiate future solutions for a sustainable world. Thinking about desired and preferred future enables students to realize the positive changes they can make and individual responsibilities in making changes (Iliško, Skrinda, \& Mičule, 2014).

Within the above mentioned context, in the face of negative consequences of a global climate change which have been usually perceived as a temporally distant threat, climate change education as a promising remedy to mitigate and adapt to negative consequences, should include and focus future time perspective as an important learning objective and learning outcome at higher education programmes.

As an emerging economy with rapid industrialization mainly depending on nonrenewable energy resources and socially and environmentally vulnerable country, Turkey urgently needs to mobilize its young population for adaptation and mitigation of global climate change. The climate change education, therefore, can be a strong instrument to enable large population of young people to acquire knowledge, values, and skills to create a sustainable future.

\section{Recommendations for Further Studies}

The findings of the present study suggested that about $19 \%$ of the variance in beliefs about occurrence; $15 \%$ of the variance in beliefs about causes; and $20 \%$ of the variance in beliefs about consequences accounted for a linear combination of the selected cognitive and psychological variables. Therefore, it must be acknowledged that further research is needed to explore other determinants that may play an important role in undergraduate students' beliefs about global climate change. Further research should examine the effects of other socio-demographic attributes other than gender, such as 
socio-economic status and situational factors including economic constrains, social pressure, advantages and disadvantages of behaviors concerning global climate change should be carefully explored in the future research.

\section{References}

Arnocky, S., Milfont, T.L., \& Nicol, J.R. (2014). Time perspective and sustainable behavior: Evidence for the distinction between consideration of immediate and future consequences. Environment and Behavior, 46(5), 556-582. doi: 10.1177/ 0013916512474987.

Bakutyte, R., Ušeckienè, L., \& Iliško, Dz. (2016). The development of implementation of learner - centered assessment in pedagogical requalification studies. Social Welfare Interdisciplinary Approach, 56-62. doi: 10.21277/sw.v2i6.264.

Balliet, D., \& Ferris, D.L. (2013). Ostracism and prosocial behavior: A social dilemma perspective. Organizational Behavior and Human Decision Processes 120(2), 298308. doi:10.1016/j.obhdp.2012.04.004.

Beck, L., \& Cable, T.T. (2011). The gifts of interpretation: Fifteen guiding principles for interpreting nature and culture. Urbana: Sagamore.

Beckenkamp, M. (2011). The social dilemma of climate change: Socio-economic implications. In W.L. Filho (Ed.), The economic, social and political elements of climate change (pp.143-152). Berlin: Springer-Verlag. doi: 10.1007/978-3-642-14776-0_10.

Besong, F., \& Holland, C. (2015). The dispositions, abilities and behaviours (DAB) framework for profiling learners' sustainability competencies in higher education. Journal of Teacher Education for Sustainability, 17(1), 5-22. doi: 10.1515/jtes2015-0001.

Bord, R. J., \& O’Connor, R. E. (1997). The gender gap in environmental attitudes: The case of perceived vulnerability to risk. Social Science Quarterly, 78(4), 830e840.

Bord, R.J., O'Connor, R.E., \& Fisher, A. (2000). In what sense does the public need to understand global climate change? Public Understanding of Science, 9(3), 205217. doi: 10.1088/0963-6625/9/3/301.

Bozdogan, A.E. (2009). Bir küresel ısınma tutum ölcegi gelistirilmesi [Developing a scale of attitudes about global warming]. EÜFBED-Fen Bilimleri Enstitüsü Dergisi [Erzincan University Journal of Science and Technology], 2(1), 35-50.

Brody, S.D., Zahran, S., Vedlitz, A., \& Grover, H. (2008). Examining the relationship between physical vulnerability and public perceptions of global climate change in the United States. Environment and Behavior, 40(1), 72-95. doi: 10.1177/ 0013916506298800.

Buckler, C., \& Creech, H. (2014). Shaping the future, we want: UN decade of education for sustainable development (2005-2014) final report. Paris: UNESCO. Retrieved from http://www.unesco.org/open-access/terms-use-ccbysa-en

Carmi, N. (2013). Caring about tomorrow: Future orientation, environmental attitudes and behaviors. Environmental Education Research, 19(4), 430-444. doi: 10.1080/ 13504622.2012. 700697.

Carmi, N., \& Arnon, S. (2014). The role of future orientation in environmental behavior: Analyzing the relationship on the individual and cultural levels. Society and Natural Resources: An International Journal, 27(12), 1304-1320. doi:10.1080/08941920. 2014.928393. 
Chew-Hung, C. (2014). Climate change education: Knowing, doing and being. London, New York: Taylor and Francis, Routledge.

Cinan, S., \& Doğan, A. (2013). Working memory, mental prospection, time orientation, and cognitive insight. Journal of Individual Differences, 34(3), 159-169. doi: 10.1027/1614-0001/a000111.

Corner, A., Venables, D., Spence, A., Poortinga, W., Demski, C., \& Pidgeon, N.F. (2011). Nuclear power, climate change and energy security: exploring British public attitudes. Energy Policy, 39, 4823-4833. doi: 10.1016/j.enpol.2011.06.037.

Corral-Verdugo, V., Fraijo-Sing, B., \& Pinheiro, Q. (2006). Sustainable behavior and time perspective: Present, past, and future orientations and their relationship with water conservation behavior. InterAmerican Journal of Psychology, 40(2), 139_ 147.

Corral-Verdugo, V., Bonnes, M., Tapia-Fonllem, C., Fraijo-Sing, B., Frias-Armenta, M., \& Carrus, G. (2009). Correlates of pro-sustainability orientation: The affinity towards diversity. Journal of Environmental Psychology 29, 34-43. doi: 10.1016/ j.jenvp. 2008.09.001.

Dietz, S., \& Stern, N. (1998). Science, values, and biodiversity. BioScience, 48(6), 441444.

Eryigit, A. (2010). A cross-age study on elementary students'value orientations, environmental optimism and environmental concern (Unpublished Master Thesis). Middle East Technical University, Ankara.

Eurobarometer (2014). Special report on climate change. Brussels: European Commission Directorate-General for Climate Action. Retrieved from http://ec.europa.eu/public_ opinion/archives /ebs/ebs_409_en.pdf

Frisk, E., \& Larson, K. (2011). Educating for sustainability: Competencies and practices for transformative action. Journal for Sustainability Education, 2. Retrieved from www.journalofsustainabilityeducation.org/wordpress/content/educating-forsustainability-competencies-practices-for-trans

Gailly, A.F. (1982). Cross-cultural differences in socialization: A comparison between Turks in Turkey, Turkish migrant in Belgium abd Belgian adolescents, with special reference to their motivational content and future time perspective. (Unpublished Doctoral dissertation). Catholic University of Louvain, Leuven, Belgium.

Gallup (2013). Gallup Poll social series: Environment and climate change. Retrieved from http://www.gallup.com/poll/161645/americans-concerns-global-warmingrise.aspx

Gibson, R. (2006). Beyond the pillars: Sustainability assessment as a framework for effective integration of social, economic and ecological considerations in significant decision-making. Journal of Environmental Assessment Policy and Management, $8(3), 259-280$.

Gifford, R. (2011). The dragons of inaction: Psychological barriers that limit climate change mitigation and adaption. American Psychological Association, 66(4), 290302. doi: $10.1037 / \mathrm{a} 0023566$.

Gifford, R., Kormos, C., \& McIntyre, A. (2011). Behavioral dimensions of climate change: drivers, responses, barriers, and interventions. Wiley Interdisciplinary Reviews: Climate Change, 2(6), 801-827. doi: 10.1002/wcc.143.

Gray, R. (2010). Is accounting for sustainability actually accounting for sustainability and how would we know? An exploration of narratives of organizations and the 
planet. Accounting Organizations and Society, 35(1), 47-62. doi: 10.1016/ j.aos.2009.04.006.

Grotzer, T., \& Lincoln, R. (2007). Educating for intelligent environmental action in an age of global warming. In S.C. Moser \& L. Dilling (Eds.). Creating a climate for change communicating climate change and facilitating social change (pp. 266280). Cambridge: Cambridge University.

Heath, Y., \& Gifford, R. (2006). Free-market ideology and environmental degradation: The case of belief in global climate change. Environment and Behavior, 38(1), 4871. doi: $10.1177 / 0013916505277998$.

Heimlich, J.E., \& Ardoin, N.M. (2008). Understanding behavior to understand behavior change: a literature review. Environmental Education Research, 14(3), 215-237. doi:10.1080/ 13504620802148881.

Hidalgo, M.C., \& Pisano, I. (2010). Determinants of risk perception and willingness to tackle climate change. A pilot study. Psychology, 1(1), 105-112.

Hulme, M. (2009). Why we disagree about climate change. Cambridge: Cambridge University Press.

Iliško, Dz., Skrinda, A. \& Mičule, I. (2014). Envisioning the future: Bachelor's and Masters' degree students' perspectives. Journal of Teacher Education for Sustainability, 16(2), 88-102.

Intergovernmental Panel on Climate Change [IPCC]. (2001). Climate change 2001: Synthesis report: Summary for policymakers. Contribution of working group II to the third assessment. Retrieved from http://www.ipcc.ch/pdf/climate-changes-2001/ synthesis-spm/synthesis-spm-en.pdf

Intergovernmental Panel on Climate Change [IPCC]. (2007). Climate change 2007: Impacts, adaptation and vulnerability. Summary for policymakers. Contribution of working group II to the fourth assessment. Retrieved from www.ipcc-wg2.org/ index.html

Ipsos MORI (2014). Global trends report 2014. Retrieved from www.ipsosglobaltrends. com /environment.html

Kabasakal, H., \& Dastmalchian, A. (2001). Introduction to the special issue on leadership and culture in the Middle East. Applied Psychology: An International Review, 50(4), 479-488.

Kagawa, F., \& Selby, D. (Eds) (2010). Education and climate change: Living and learning in interesting times. New York: Routledge.

Kahraman, S., Yalçın, M., Özkan, E., \& Aggül, F. (2008). Sınıf ogretmenligi ogrencilerinin kuresel isinma konusundaki farkindaliklari ve bilgi duzeyleri [Pre-service elementary school teachers' awareness and knowledge about global climate change]. Gazi Eğitim Fakültesi Dergisi [Gazi University Journal of Gazi Educational Faculty], 28(3), 249-263.

Keinonen, T., Palmberg, I., Kukkonen, J., Yli-Panula, E., Persson, C., \& Vilkonis, R. (2016). Higher education students' perceptions of environmental issues and media coverage. Discourse and Communication for Sustainable Education, 7(1), 5-22. doi: 10.1515/dcse-2016-0001.

Kılınç, A., Boyes, E., \& Stanisstreet, M. (2011). Turkish school students and global warming: beliefs and willingness to act. Eurasia Journal of Mathematics, Science \& Technology Education, 7(2), 121-134.

Komorita, S.S., \& Parks, C.D. (1994). Social dilemmas. Boulder: Westview Press. 
Leiserowitz, A. (2005). American risk perceptions: Is climate change dangerous? Risk Analysis, 25(6), 1433-1442.

Leiserowitz, A., Maibach, E., Roser-Renouf, C. \& Hmielowski, J. (2012) Global warming's six Americas, March 2012 \& Nov. 2011. Yale University and George Mason University. New Haven, CT: Yale Project on Climate Change Communication. Retrieved from http://environment.yale.edu/climate/files/Six-Americas-March2012.pdf

Liberman, N., \& Trope, Y. (2008). The psychology of transcending the here and now. Science, 322, 1201-1205.

Lorenzoni, L., Nicholson-Cole, S., \& Whitmarsh, L. (2007). Barriers perceived to engaging with climate change among the UK public and their policy implications. Global Environmental Change, 17(3-4), 445-459. doi: 10.1016/j.gloenvcha.2007. 01.004.

Maibach, E.W., Leiserowitz, A., Roser-Renouf, C., \& Mertz, C.K. (2011). Identifying like-minded audiences for global warming public engagement campaigns: An audience segmentation analysis and tool development. PLoS ONE, 6(3), e17571. doi: 10.1371/journal.pone.0017571.

Makrakis, V., Gkotzos, D., \& Larios, N. (2013). ICT-enabled climate change education and children rights. Journal of Teacher Education for Sustainability, 14(2), 89110. doi: 10.2478/v10099-012-0011-y.

Malka, A., Krosnick, J.A., \& Langer, G. (2009). The association of knowledge with concern about global warming: Trusted information sources shape public thinking. Risk Analysis, 29(5), 633-647. doi: 10.1111/j.1539-6924.2009.01220.x.

McCright, A. M. (2010). The effects of gender on climate change knowledge and concern in the American public. Population and Environment, 32(1), 66e87.

McCright, A.M., Dunlap, R.E., \& Xiao, C. (2013). Perceived scientific agreement and support for government action on climate change in the USA. Climatic Change, 119, 511-518.

Meier, T., \& Christen, O. (2012). Gender as a factor in an environmental assessment of the consumption of animal and plant-based foods in Germany. The International Journal of Life Cycle Assessment, 17(5), 550e564.

Messick, D. M., \& McClelland, C. L. (1983). Social traps and temporal traps. Personality and Social Psychology Bulletin, 9(1), 105-110. doi:10.1177/0146167283091015.

Milfont, T.L. (2010). The psychological meaning of preservation and utilization attitudes: A study using the natural semantic network technique. Psycology, 1, 123-136.

Milfont, T.L. (2012). The interplay between knowledge, perceived efficacy, and concern about global warming and climate change: A one-year longitudinal study. Risk Analysis, 32, 1003-1020.

Milfont, T.L., \& Demarque, C. (2015). Understanding environmental issues with temporal lenses: Issues of temporality and individual differences. In M. Stolarski, N. Fieulaine, \& W.van Beek (Eds.), Time perspective theory; review, research \& application: Essays in honor of Philip G. Zimbardo (pp. 371-383). New York: Springer. doi: 10.1007/978-3-319-07368-2_24.

Milfont, T.L., \& Duckitt, J. (2010). The environmental attitudes inventory: A valid and reliable measure to assess the structure of environmental attitudes. Journal of Environmental Psychology, 30, 80-94. 
Milfont, T.L., Abrahamse, W., \& McCarthy, N. (2011). Spatial and temporal biases in assessments of environmental conditions in New Zealand. New Zealand Journal of Psychology, 40, 56-67.

Milfont, T.L., \& Gouveia, V. V. (2006). Time perspective and values: An exploratory study of their relations to environmental attitudes. Journal of Environmental Psychology, 26(1), 72-82. doi: 10.1016/j.jenvp.2006.03.001.

Milfont, T.L., Wilson, J., \& Diniz, P. (2012). Time perspective and environmental engagement: A meta-analysis. International Journal of Psychology, 47(5), 325334. doi: 10.1080/00207594.2011.647029.

Ministry of Environment and Urbanization (2012). İklim değişikliğinin farkında mıyız? [Are we aware of climate change?]. Ankara: Ministry of Environment and Urbanization.

Nilsson, A., von Borgstede, C, \& Biel, A. (2004). Willingness to accept climate change strategies: the effect of values and norms. Journal of Environmental Psychology, 24, 267-277.

Nolet, V. (2009). Preparing sustainability-literate teachers. Teachers College Record, 111(2), 409-442.

O’Connor, R.E., Bord, R.J., \& Fisher, A. (1999). Risk perceptions, general environmental beliefs, and willingness to address climate change. Risk Analysis, 79, 461-471.

Ozdem, Y., Dal, B., Ozturk, N., Sonmez, D., \& Alper, U. (2014). What is that thing called climate change? An investigation into the understanding of climate change by seventh-grade students. International Research in Geographical and Environmental Education, 23(4), 294-313. doi: 10.1080/10382046.2014.946323.

Park, H.S., \& Vedlitz, A. (2013). Climate hazards and risk status: Explaining climate risk assessment, behavior, and policy support. Sociological Spectrum, 33(3), $219 \mathrm{e} 239$.

Petrocelli, J.V. (2003). Factor validation of the consideration of future consequences scale: Evidence for a short version. The Journal of Social Psychology, 143(4), 405413.

Pike, C., Doppelt, B., \& Herr, M. (2010). Climate communications and behavior change: A guide for practitioners. Oregon: The Climate Leadership Initiative. Retrieved from www.climateaccess.org/sites/default/files/Climate \%20Communications \% 20and\%20Behavior\%20Change.pdf

Pipere, A., Veisson M., \& Salite, I. (2015). Developing research in teacher education for sustainability: UN DESD via the Journal of Teacher Education for Sustainability. Journal of Teacher Education for Sustainability, 17(2), 5-43, doi: 10.1515/jtes2015-0009.

Poortinga, W., Spence, A., Whitmarsh, L., Capstick, S., \& Pidgeon, N. (2011). Uncertain climate: an investigation into public scepticism about anthropogenic climate change. Global Environmental Change, 21, 1015-1024. doi: 10.1016/j.gloenvcha.2011. 03.001.

Powell, R.B., \& Ham, S.H. (2008). Can ecotourism interpretation really lead to proconservation knowledge, attitudes and behavior? Evidence from the Galapagos Islands. Journal of Sustainable Tourism, 16, 467-89.

Pruneau, D., Kerry, J., Freiman, V., Langis, J., \& Bizid, M. (2016). Perceived affordances, tensions, and complementarities in the physical and digital environments frequented by future teachers. Discourse and Communication for Sustainable Education, 7(1), 68-81. doi: 10.1515/dcse-2016-0005. 
Rabinovich, A., Morton, T., \& Postmes, T. (2010). Time perspective and attitudebehavior consistency in future-oriented behaviors. British Journal of Social Psychology, 49(1), 69-89. doi: 10.1348/014466608X401875.

Reser, J.P., Bradley, G.L., Glendon, A. I., Ellul, M.C., \& Callaghan, R. (2012). Public risk perceptions, understandings, and responses to climate change and natural disasters in Australia and Great Britain, Gold Coast: National Climate Change Adaptation Research Facility.

Sahin, E. (2013). Predictors of Turkish elementary teacher candidates' energy conservation behaviors: An approach on value-belief-norm theory. International Journal of Environmental and Science Education, 8(2), 269-283. doi: 10.12973/ijese. 2013.204a.

Sahin, E., Ertepinar, H., \& Teksoz, G. (2012). University students’ behaviors pertaining to sustainability: A structural equation model with sustainability-related attributes. International Journal of Environmental and Science Education, 7(3), 459-478.

Salite, I. (2015). Searching for sustainability in teacher education and educational research: Experiences from the Baltic and Black Sea Circle Consortium for educational research. Discourse and Communication for Sustainable Education, 6, 21-29.

Scannell, L., \& Gifford, R. (2013). Personally relevant climate change: The role of place attachment and local versus global message framing in engagement. Environment and Behavior, 45(1), 60-85.

Schultz, P.W., Shriver, C., Tabanico, J.J., \& Khazian, A.M. (2004). Implicit connections with nature. Journal of Environmental Psychology, 24(1), 31-42. doi: 10.1016/ S0272-4944(03)00022-7.

Semenza, J.C., Hall, D.E., Wilson, D.J., Bontempo, B.D., Sailor, D.J., \& George, L.A. (2008). Public perception of climate change: Voluntary mitigation and barriers to behavior change. American Journal of Preventive Medicine, 35(5), 479-487. doi: 10.1016/j.amepre.2008.08.020.

Senel, H., \& Gungor, B. (2009). Universite ögrencilerinin küresel isinma hakkindaki bilgilerinin ve kavram yanilgilarinin tespiti [Exploring university students' misconceptions and knowledge about global warming]. E-Journal of New World Sciences Academy, 4(4), 1207-1225. Retrieved from: http://dergipark.ulakbim.gov.tr/ nwsaedu/article/download/5000063529/pdf_140.

Sever, D. (2013). Türkiye ve İngiltere'deki fen bilimleri alanında ögrenim gören ögretmen adaylarinin küresel isinmaya yönelik düsünceleri [Views of prospective science teachers in Turkey and UK about global warming]. Ilkögretim Online [Elementary Education Online], 12(4), 1212-1221.

Shao, W. (2012). Understanding public perceptions of global warming. Unpublished Doctoral Thesis. Louisiana State University.

Sircova, A., van de Vijver, F. J. R., Osin, E., Milfont, T. L., Fieulaine, N., KislaliErginbilgic, A., \& Zimbardo, P. G. (2015). Time perspective profiles of cultures. In M. Stolarski, N. Fieulaine, \& W. van Beek (Eds.), Time perspective theory; review, research and application: Essays in honor of Philip G. Zimbardo (pp. 169-187). New York: Springer. doi: 10.1007/978-3-319-07368-2.

Spence, A., Poortinga, W., \& Pidgeon, N. (2012). The psychological distance of climate change. Risk Analysis, 32(6), 957-972. doi: 10.1111/j.1539-6924.2011.01695.x.

Sterling, S. (2004). Sustainable education: Re-visioning learning and change. Bristol: Schumacher Briefing Green Books. 
Strathman, A., Gleicher, F., Boninger, D.S., \& Edwards, C.S. (1994). The Consideration of future consequences: Weighing immediate and distant outcomes of behavior. Journal of Personality and Social Psychology, 66(4), 742-752.

Sundblad, E.L., Biel, A., \& Gärling, T. (2008). Knowledge and confidence in knowledge about climate change among experts, journalists, politicians and laypersons. Environment and Behavior, 41(2), 281-302. doi: 10.1177/0013916508314998.

Swim, J., Clayton, S., Doherty, T., Gifford, R., Howard, G., Reser, J., Stern, P., \& Weber, E. (2009). Psychology and global climate change: Addressing a multi-faceted phenomenon and set of challenges. A report by the American Psychological Association's task force on the interface between psychology and global climate change. Retrieved from: www.apa.org/science/about/publications/climate-change.aspx

Thompson, S. C., \& Barton, M.A. (1994). Ecocentric and anthropocentric attitudes toward the environment. Journal of Environmental Psychology, 14(2), 149-157. doi: 10.1016/S0272-4944(05)80168-9.

Trope, Y.L., Liberman, N., \& Wakslak, C. (2007). Construal levels and psychological distance: Effects on representation, prediction, evaluation, and behavior. Journal of Consumer Psychology, 17(2), 83-95. doi:10.1016/S1057-7408(07)70013-X.

Trope, Y. L., \& Liberman, N. (2010). Construal-level theory of psychological distance. Psychological Review, 117(2), 440-463. doi:10.1037/a0018963.

Tuncer (2008). University students' perception on sustainable development: A case study from Turkey. International Research in Geographical and Environmental Education, 17(3), 212-226. doi: 10.1080/10382040802168297.

Tuncer, G., Ertepinar, H., Tekkaya, C., \& Sungur, S. (2005). Environmental attitudes of young people in Turkey: effects of school type and gender. Environmental Education Research, 11(2), 215-233.doi: 10.1080/1350462042000338379.

UNESCO (2014). Roadmap for implementing the global action programme on education for sustainable development. Paris, France: UNESCO. Retrieved from http://unesdoc.unesco.org/images/0023/002305/230514e.pdf

van der Linden, S. (2014). On the relationship between personal experience, affect and risk perception: The case of climate change. European Journal of Social Psychology, 44, 430-440. doi: 10.1002/ejsp.2008.

Wade-Benzoni, K.A., Hernandez, M., Medvec, V., \& Messick, D. (2008). In fairness to future generations: The role of egocentrism, uncertainty, power, and stewardship in judgments of intergenerational allocations. Journal of Experimental Social Psychology, 44, 233-245.

Whitmarsh, L. (2009a). Behavioural responses to climate change: Asymmetry of intentions and impacts. Journal of Environmental Psychology, 29(1), 13-23. doi:10.1016/ j.jenvp.2008.05.003.

Whitmarsh, L. (2009b). What's in a name? Commonalities and differences in public understanding of "global warming" and "climate change". Public Understanding of Science, 18, 401-420. doi: 10.1177/0963662506073088.

Whitmarsh, L. (2011). Scepticism and uncertainty about climate change: dimensions, determinants and change over time. Global Environmental Change, 21, 690-700.

Wiek, A., Withycombe, L., \& Redman, C.L. (2011). Key competencies in sustainability: A reference framework for academic program development. Sustainability Science, 6, 203-218. 
Yilmaz, O., Boone, W. J., \& Anderson, H. O. (2004). Views of elementary and middle school Turkish students toward environmental issues. International Journal of Science Education, 26(12), 1527-1546.

Zelezny, L.C., \& Chua, P.P., \& Aldrich, C. (2000). Elaborating on gender differences in environmentalism. Journal of Social Issues, 56, 443-457.

Zimbardo, P.G., \& Boyd, J.N. (1999). Putting time in perspective: A valid, reliable, individual-differences metric. Journal of Personality and Social Psychology, 77, 1271-1288.

Zimbardo, P.G., Keough, K.A., \& Boyd, J.N. (1997). Present time perspective as a predictor of risky driving. Personality and Individual Differences, 23(6), 10071023. doi: 10.1016/S0191-8869(97)00113-X.

Zimmerman, M.R.K. (2011). The consensus on the consensus: An opinion survey of earth scientists on global climate change. Chicago: The Hearthland Institute.

Correspondence relating this article needs to be addressed to Dr. Deniz Ateş, Middle East Technical University, Faculty of Education, Elementary Education. Email: dates@metu.edu.tr 